
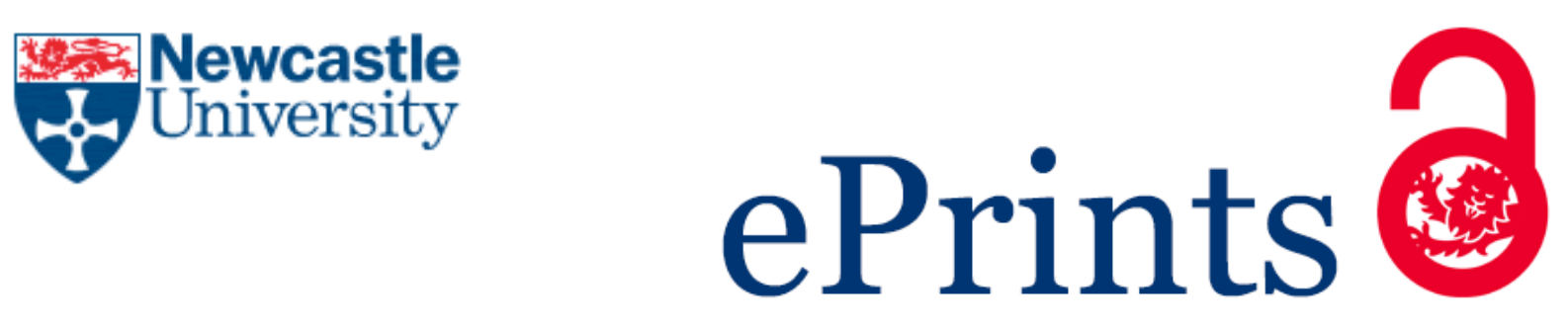

Juggins S, Kelly M, Allott T, Kelly-Quinn M, Monteith D.

A Water Framework Directive-compatible metric for assessing acidification in

UK and Irish rivers using diatoms.

Science of the Total Environment 2016

DOI: $\underline{\text { http://dx.doi.org/10.1016/j.scitotenv.2016.02.163 }}$

Copyright:

(C) 2016. This manuscript version is made available under the CC-BY-NC-ND 4.0 license

Date deposited:

$16 / 03 / 2016$

Embargo release date:

09 March 2017

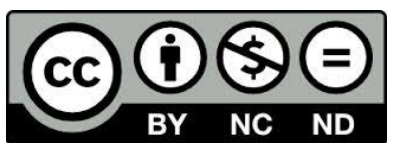

This work is licensed under a

Creative Commons Attribution-NonCommercial-NoDerivatives 4.0 International licence 


\title{
A Water Framework Directive-compatible metric for assessing acidification in UK and Irish rivers using diatoms
}

\author{
Steve Juggins ${ }^{1^{*}}$, Martyn Kelly ${ }^{2}$, Tim Allott $^{3}$, Mary Kelly-Quinn ${ }^{4}$ and Don \\ Monteith ${ }^{5}$
}

${ }^{1}$ School of Geography, Politics and Sociology, Newcastle University, Newcastle upon Tyne NE1 7RU, UK. Stephen.Juggins@ncl.ac.uk

${ }^{2}$ Bowburn Consultancy, 11 Monteigne Drive, Bowburn, Durham DH6 5QB, UK. MGKelly@bowburn-consultancy.co.uk

${ }^{3}$ School of Environment and Development, University of Manchester, Manchester M13 9PL, UK. tim.allott@manchester.ac.uk

${ }^{4}$ School of Biology and Environmental Science, University College Dublin, Dublin 4, Ireland. mary.kelly-quinn@ucd.ie

${ }^{5}$ NERC Centre for Ecology \& Hydrology, Lancaster Environment Centre, Lancaster, LA1 4AP.donm@ceh.ac.uk

${ }^{*}$ Corresponding author

\begin{abstract}
Freshwater acidification continues to be a major problem affecting large areas of Europe, and while there is evidence for chemical recovery, similar evidence for biological recovery of freshwaters is sparse. The need for a methodology to identify waterbodies impacted acidification and to assess the extent of biological recovery is relevant to the EU Water Framework Directive, which requires methods to quantify differences in biology between impacted and unimpacted or reference sites. This study presents a new WFD-compliant metric based on diatoms (Diatom Acidification Metric: DAM) for assessing the acidification status of rivers. A database of 558 benthic diatom samples and associated water chemistry data was assembled. Diatom taxa were assigned to one of 5 indicator classes on the basis of their $\mathrm{pH}$ optimum, assessed using Gaussian logistic regression, and these indicator values used to calculate a DAM score for each site using weighted averaging. Reference sites were selected on the basis of their acid neutralising capacity (ANC) and calcium concentration, and a regression model developed to predict expected DAM for each site using $\mathrm{pH}$ and total organic carbon (TOC) concentration. Site-specific DAM scores were used to calculate ecological quality ratios ranging from $\geq 1$, where the diatom assemblage showed no impact, to (theoretically) 0 , when the diatom assemblage was indicative of major anthropogenic activities. The boundary between 'high' and 'good' status was defined as the 25th percentile of Ecological Quality Ratios (EQRs) of all reference sites. The boundary between 'good' and 'moderate' status was set at the point at which nutrient-sensitive and nutrient-tolerant taxa were present in equal relative abundance. The methodology was evaluated using
\end{abstract}


long-term data from 11 sites from the UK Uplands Waters Monitoring Network and is shown to perform well in discriminating naturally acid from acidified sites.

\section{Introduction}

There is a long history of research into the response of diatoms to $\mathrm{pH}$, from pioneering studies of Hustedt (1937-39) to palaeoecological studies on the causes of lake acidification (Flower and Battarbee, 1983; Renberg and Hellberg, 1982), recovery, and the effects of remediation strategies (Allott et al., 1992; Battarbee et al., 2014b; Guhrén et al., 2006). The focus of this research has been primarily on lakes, where the relationship between diatom assemblages and $\mathrm{pH}$ can be modelled with a precision of approximately $\pm 0.3 \mathrm{pH}$ units (Birks et al., 1990). This work was important in highlighting the role of acid deposition in the acidification of surface waters in large areas of both Europe and North America (Battarbee et al., 2010a) and, ultimately, in shaping government policy (Derwent and Wilson, 1992). Treaties aimed at limiting transboundary air pollution have led to large reductions in the emission and deposition of pollutants and chemical data show recovery of freshwaters since the 1990s (Stoddard et al., 1999). However, the evidence for biological recovery is scarce, with many areas still impacted by episodic (Feeley et al., 2013; Kowalik et al., 2007) or chronic acidification (Ormerod and Durance, 2009). Consequently, there is a continuing need to identify and monitor affected freshwaters and quantify their recovery towards a target state.

Acidification was one of a number of impacts that demonstrated the deleterious effects of human activities on the ecology and ecological services of aquatic environments, and which provided the impetus for the Water Framework Directive (WFD: European Union, 2000). A core concept of the WFD is that ecological status (defined as “... an expression of the structure and functioning of aquatic ecosystems”, WFD Article 2) is determined by reference to the condition of an ecosystem that would prevail in the absence of significant human disturbances. The magnitude of any disturbance or impact is then expressed as an Ecological Quality Ratio (EQR) calculated as the ratio of metrics defining observed and expected states. Defining the "expected" state has been a major challenge for the past decade (Pardo et al., 2012). In principle, palaeoecological studies provide a powerful means for doing this albeit in standing waters only (Bennion et al., 2010). Such an approach can be used to identify lakes whose $\mathrm{pH}$ has changed little in recent times (Battarbee et al., 2010b). These can then serve as "reference sites" (sensu Wallin et al., 2003) from which properties of biological quality elements in their nearpristine state can be measured for use as “expected” values for EQR calculations.

Although various metrics for assessing $\mathrm{pH}$ in running waters using diatoms have been developed (Andrén and Jarlman, 2008; Coring, 1996; Kwandrans, 2007; Van Dam and Mertens, 1995) none is suitable as a WFD acidification assessment system for two reasons: they do not address the issue of "expected" values of metrics under conditions of "no, or only very minor, anthropogenic alterations" (European Union, 2000), and they do not provide an ecological basis for setting quality status boundaries. The former is particularly significant as it is important that ecological status assessments can distinguish those water bodies which have been acidified by human causes from those which are naturally acidic. An ecological rationale for setting boundaries is also important as the WFD provides, in Annex V (European Union, 2000), ecological criteria 
by which ecological status should be assessed, and expects member states to take action to improve water quality in those water bodies that achieve moderate status or less.

In this paper we describe a new diatom-based metric for assessing the acidification status of rivers. Our metric is calibrated against a database of reference sites in the UK and Ireland enabling an EQR and ecological status class to be calculated for any new diatom sample. Thus, our method is compliant with the requirements of the WFD and will form part of the suite of tools for the holistic assessment of the quality element "macrophytes and phytobenthos" in the UK and Ireland.

\section{Methods}

\subsection{Dataset}

The dataset used to derive the diatom metric comprised 558 samples from 435 sites with data on diatom species composition and associated water chemistry, and was assembled from a number of previous projects: UK Uplands Water Monitoring Network (UKUWMN, Formerly the UK Acid Waters Monitoring Network: Patrick et al., 1996: $\mathrm{N}=32$ ), the Welsh Acids Waters Survey (Reynolds et al., 1999: N=203) the Critical Loads of Acidity and Metals project (Kernan and Curtis, 2000: N=78) and the FORWATER project (Kelly-Quinn et al., 2008: $\mathrm{N}=245$ ). These studies focussed on those areas of the UK and Ireland associated with slow-weathering geology, low alkalinity and, therefore, susceptibility to acidification. Sampling areas were principally in upland regions of south-west England, the Pennines, Wales, the Lake District, Scotland, and Ireland, along with lowland samples from the New Forest (Hampshire) and Ashdown Forest (Sussex). Sampling and analytical methodologies follow those of Kelly et al. (2008) and are compliant with European standards (CEN, 2003, 2004). Samples were collected by brushing the upper surface of cobble-sized stones using a toothbrush and storing the resulting suspension in a plastic bottle for transport to the laboratory where they were digested using hydrogen peroxide (Battarbee, 1986) and permanent slides prepared using Naphrax high resolution mountant (Brunel Microscopes Ltd, UK). At least 300 valves were identified using 1000× magnification oil immersion objectives. Taxonomy followed Krammer and Lange-Bertalot (1986-1991) and Hartley et al. (1996). All nomenclature was adjusted to that used by Whitton et al. (1998) which follows conventions in Round et al. (1990) and Fourtanier and Kociolek (1999-2003). Water chemistry samples were collected at the diatom sampling sites between 4 and 12 times per year and analysed using methods described in Monteith et al. (2014) for $\mathrm{pH}$, acid neutralising capacity (ANC), calcium, and total organic carbon (TOC), and expressed as annual mean values. Species-environment relationships in the data were explored using canonical correspondence analysis (ter Braak, 1986) and the relative importance of $\mathrm{pH}$ and TOC in accounting for variation in diatom species composition was assessed using CCA-based variance partitioning (Borcard et al., 1992). All numerical analyses were performed using $\mathrm{R}$ software (R Core Team, 2015) with the vegan package (Oksanen et al., 2015).

\subsection{Definition of reference conditions}

A pre-requisite for reference (i.e. non-acidified) waters is that concentrations of base cations are in balance, or exceed, concentrations of strong acid anions, i.e. ANC is positive. In contrast, waters with negative ANC, i.e. where the surfeit of acid anions 
relative to base cations, tend to be balanced by elevated concentrations of acid cations $\left(\mathrm{H}^{+}\right.$and $\left.\mathrm{Al}^{3+}\right)$ and can almost invariably be considered to be acidified. The use of a critical ANC value ( $\mathrm{ANC}_{\text {crit }}$ ) to determine the threshold above which damage from acidification is unlikely to occur forms the basis of the acidification critical loads concept, and values ranging from $0-50 \mu \mathrm{eq} \mathrm{L}^{-1}$ have been applied internationally, primarily to reflect risk of damage to salmonid populations (Lien et al., 1996). An $\mathrm{ANC}_{\text {crit }}$ of $20 \mu \mathrm{eq} \mathrm{L}^{-1}$ is currently recommended for UK waters (Curtis et al., 2014).

ANC falls as acidification proceeds but, because it is a function of a site's buffering capacity, ANC alone is not sufficient to determine its acidification status. For example, highly oligotrophic and dilute non-acidified waters such as those occurring in areas of high rainfall and very low geological weathering rates, can exhibit relatively low positive ANC but still support a healthy aquatic ecosystem providing $\mathrm{Al}^{3+}$ concentrations are low (e.g. $<10 \mu \mathrm{g} \mathrm{L}^{-1}$ ). On the other hand, waters with similarly low, or even higher, levels of ANC may reflect some degree of acidification where concentrations of TOC, base cations and $\mathrm{Al}^{3+}$ are higher. Hence, McCartney et al. (2003) recognised that a range of ANC values might be necessary to determine risk of damage to brown trout populations depending on the relative contributions of $\mathrm{H}^{+}, \mathrm{Al}^{3+}$ and TOC. This was developed further by Malcolm et al. (2014) who observed that $\mathrm{Al}^{3+}$ concentrations provided by far the strongest single indicator of harm to brown trout, and observed that levels of ANC associated with an $80 \%$ likelihood of occurrence of brown trout fry varied substantially between UWMN sites.

The concept of a variable $\mathrm{ANC}_{\text {crit }}$ provided the basis for the development of a WFD macroinvertebrate tool for UK lakes by Monteith and Simpson (2007). Due to a paucity of TOC and $\mathrm{Al}^{3+}$ data available for their macroinvertebrate-water chemistry calibration dataset, they first established a relationship between ANC, calcium, and $\mathrm{Al}^{3+}$ concentration in UWMN water samples. This relationship was then used to determine ANC levels at which $\mathrm{Al}^{3+}$ was likely to exceed potentially harmful concentrations for a given $\mathrm{Ca}^{2+}$ concentration. The approach was supported by observations from both palaeoecological and hydrochemical modelling exercises (Table 1). In this study, therefore, sites defined as "high status" have high ANC relative to Ca and have been used as reference sites.

Table 1. Damage matrix of Monteith and Simpson (2007) (see text for details). Letters represent likely ecological status with respect to damage from acidification: $\mathbf{H}=$ high; $\mathbf{G}=$ good; $\mathbf{M}=$ moderate; $\mathbf{P}=$ poor; $\mathbf{B}=$ bad. Numbers in the cells indicate numbers of reference (upper) and non-reference (lower) samples in each ANC / Ca class. 


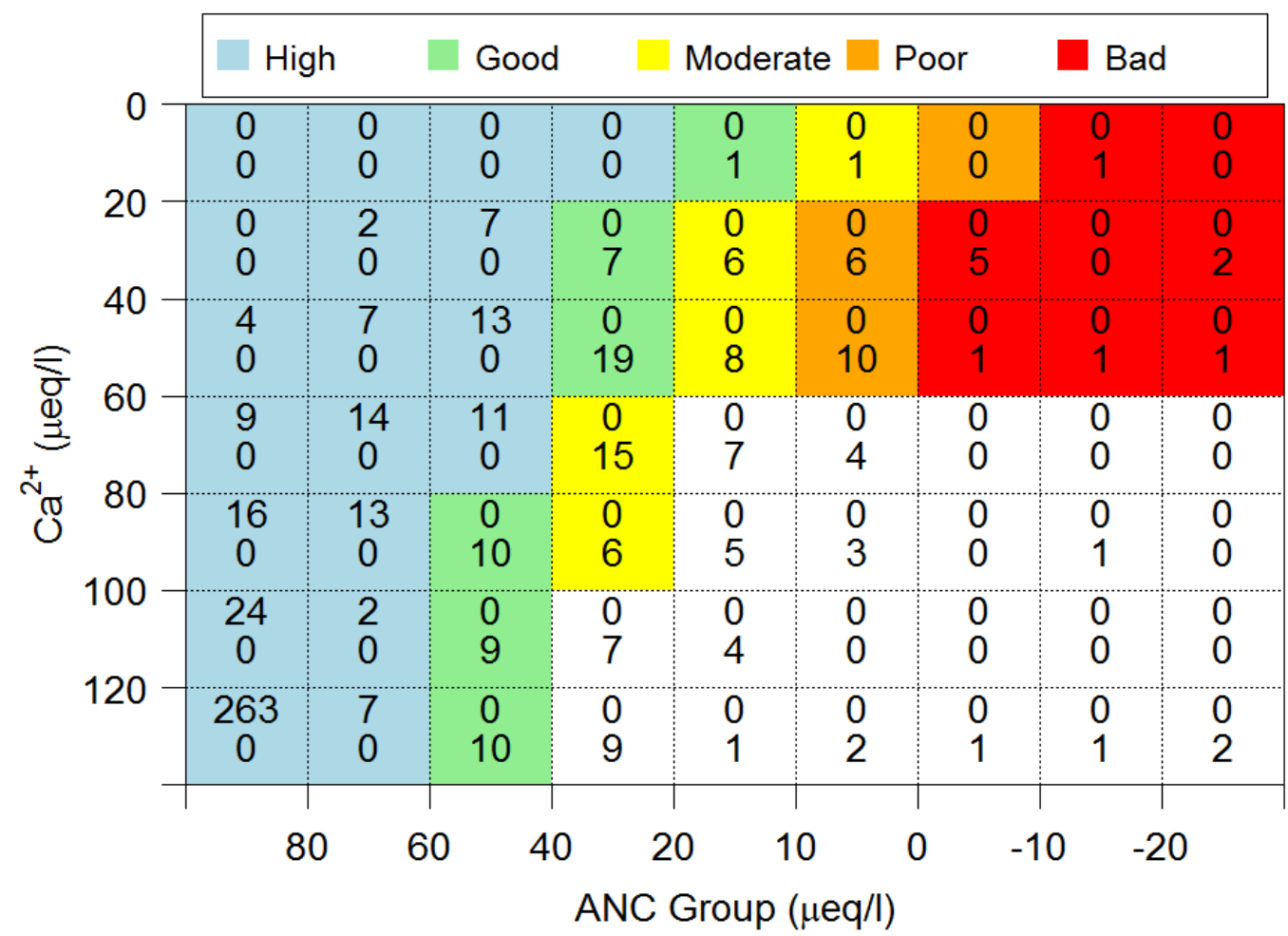

The approach used here differs from that recommended to define reference conditions for other pressures, where sites are screened using land-use data (Stoddard et al., 2006; Wallin et al., 2003) which would not be suitable for this type of pressure as, except for some forested catchments, land-use rarely provides a strong guide to the likelihood of acidification. This screening process yielded 369 potential reference samples, although 263 of these were associated with the highest $\mathrm{Ca}^{2+}$ class $\left(>120 \mu \mathrm{eq} \mathrm{L}^{-1}\right)$.

\subsection{Derivation of metric}

The metric was derived in a similar way to the Trophic Diatom Index (TDI) implemented in the nutrient DARLEQ model (Kelly et al., 2008), except that the TDI was replaced by a new 'Diatom Acidification Metric' (DAM). Specifically, we first, derived $\mathrm{pH}$ optimum or preference value for each taxon using Gaussian logistic regression (ter Braak and Looman, 1986) and assigned each taxon to one of $5 \mathrm{pH}$ groups on the basis of these optima as follows: $1=\mathrm{pH}<5.0,2=\mathrm{pH} 5.0-5.6,3=\mathrm{pH} 5.6-7.0,4=\mathrm{pH} 7.0-8.0,5=\mathrm{pH}$ $>8$ (Appendix 1). The ranges of the five $\mathrm{pH}$ classes approximately match the $\mathrm{pH}$ classes defined by Hustedt (1937-39; see van Dam et al., 1994). Of 131 taxa recorded in this study in ten or more samples, 97 were recognised by Hustedt (1937-39) and, of these, $43 \%$ had identical classes in the two systems whilst $86 \%$ differed by no more than one class. The taxon scores so derived were then used to calculate an acidity (DAM) score for each sample by weighted averaging (ter Braak and Barendregt, 1986), that is, by taking an average of the taxon indicator values weighted by the taxon relative abundance (Equation 1). The final DAM scores were then rescaled to run from 0 (low $\mathrm{pH}$ ) to 100 (high $\mathrm{pH}$ ) (Equation 2). 
$W M S=\sum_{j=0}^{n} a_{j} s_{j} / \sum_{j=0}^{n} a_{j}$

Equation 1

$D A M=(W M S-1) * 25$

Equation 2

where $\mathrm{a}_{\mathrm{j}}=$ abundance or proportion of valves of taxon $\mathrm{j}$ in sample, $\mathrm{s}_{\mathrm{j}}=\mathrm{pH}$ preference class $(1-5)$ of taxon j; WMS = weighted mean score.

The resulting DAM sample scores show a higher correlation to $\mathrm{pH}(\mathrm{r}=0.81)$ than ANC $(\mathrm{r}=0.65)$ indicating that the metric is a good indicator of acidity, rather than acidification.

\section{Results}

\subsection{Description of dataset and preliminary ordinations}

A total of 365 species or varieties of diatoms were identified. The most frequentlyrecorded taxa were Eunotia exigua (65\% of samples), Tabellaria flocculosa (60\%), Achnanthidium minutissimum sensu lato (52\%), and E. incisa (44\%); 45 taxa were found in fewer than 10 samples. The maximum relative abundance of any taxon in a sample was $97 \%$ for Eunotia exigua followed by $96 \%$ for E. intermedia. Some 57 taxa occurred at $20 \%$ or more in at least one sample.
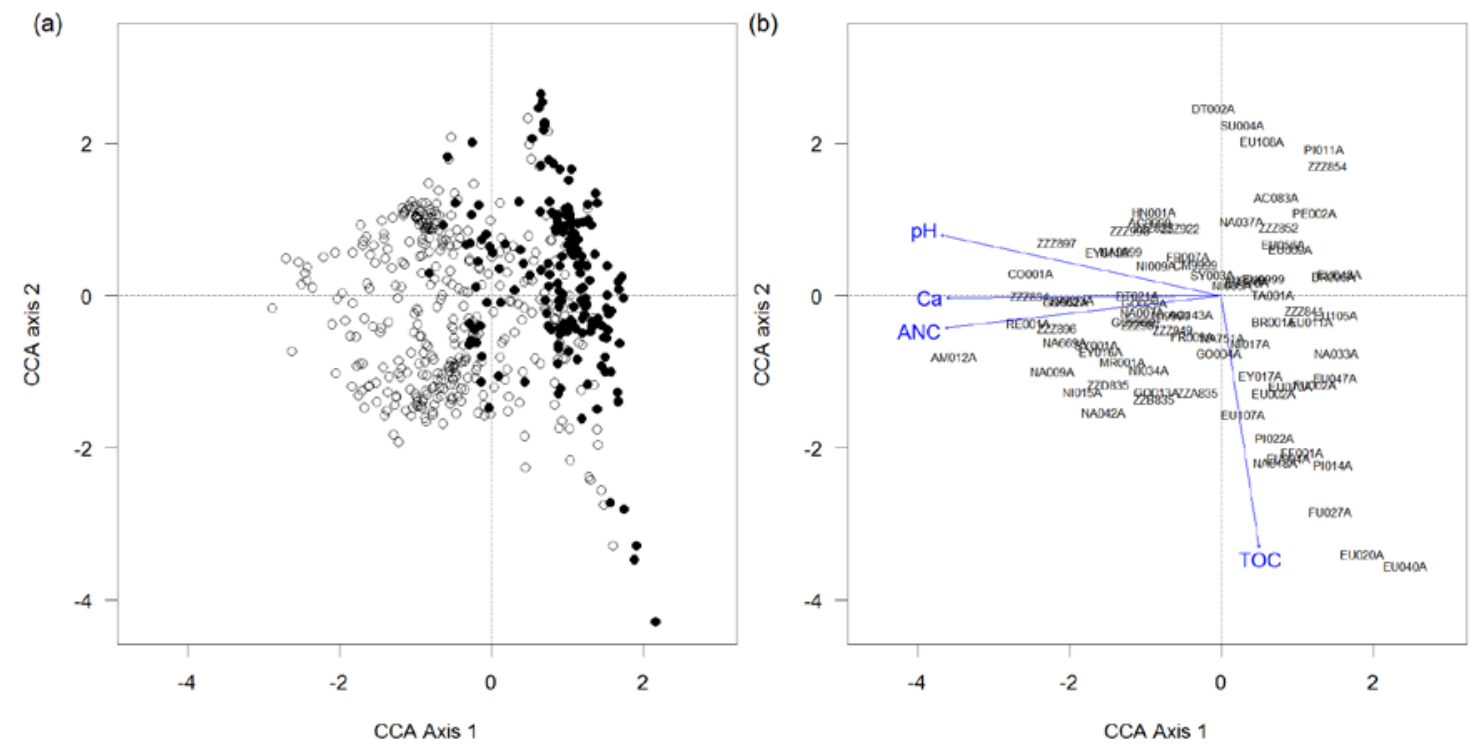

Figure 1. Canonical correspondence analysis triplot showing samples (left) and taxa and environmental variables (right). Only taxa with maximum relative abundance greater than $30 \%$ are included. Reference sites are plotted as open circles. Taxon codes and names are listed in Appendix 1.

Figure 1 shows a canonical correspondence analysis (CCA) triplot of the full dataset. Axis 1 accounts for $4.1 \%$ of the variation in the diatom data and is related to the acidity gradient. Axis 2 accounts for an additional $2.6 \%$ of variation and is primarily related to TOC. Both axes are highly significant $(\mathrm{p}=0.001$, Monte Carlo permutation test, 999 permutations).

Circumneutral taxa such as Cocconeis placentula (CO001A) and Amphora pediculus (AM012A) typically had positive scores on axis 1; whilst acid-tolerant taxa had low or 
slightly negative scores and were arranged along the second axis, which may reflect, in part, a gradient from taxa typical of habitats rich in humic materials (e.g. Frustulia saxonica: FR027A) having low scores on axis 2 whilst those typical of clear water acid habitats (e.g. Peronia fibula: PE002A) tending to have higher scores. Variance partitioning of the diatom data with respect to $\mathrm{pH}$ and TOC shows that individually these variables account for a total of $3.8 \%$ and $2.4 \%$ of the variation in diatom species composition. The shared component of variation is only $0.5 \%$ indicating that the effects of $\mathrm{pH}$ and TOC are largely independent in this dataset.

The composition of samples taken from reference sites varied from domination by circumneutral taxa such as Achnanthidium minutissimum sensu lato when $\mathrm{Ca}^{2+}$ concentrations were $>100 \mu \mathrm{eq} \mathrm{L}^{-1}$ to domination by Eunotia spp and Tabellaria flocculosa in the most softwater sites. Alongside A. minutissimum, Fragilaria capucina var. gracilis was also abundant, and Brachysira vitrea and Gomphonema parvulum (and varieties) were common. Achnanthes oblongella was rare to absent when $\mathrm{Ca}^{2+}>300 \mu \mathrm{eq}$ $\mathrm{L}^{-1}$ but formed up to about $40 \%$ of the total when $\mathrm{Ca}^{2+}=100 \mu \mathrm{eq} \mathrm{L}^{-1}$, before declining

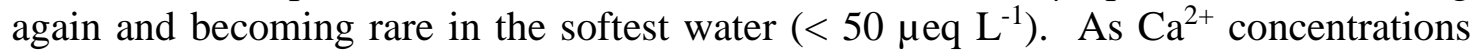
decline, so the proportion of Eunotia spp (especially E. exigua, E. intermedia and E. incisa) increased, along with Peronia fibulata, Pinnularia subcapitata and $P$. appendiculata. Navicula sensu stricto and Nitzschia spp were both relatively rare in these waters.

\subsection{Calculation of EQRs and class boundaries}

Calculation of an EQR for a sample requires an estimate of the "expected" value of DAM for the site under reference conditions. To develop a useful metric that can be applied in routine monitoring this estimate has to be derived from data that are currently collected, or from variables that agencies do not routinely measure but that could be added relatively easily. The "expected" values should also be estimated using variables not related to the underlying pressure of interest, since the "expected" or reference value is an intrinsic characteristic of the site that is independent of the pressure gradient. Given these criteria we tested models using $\mathrm{Ca}^{2+}$ and TOC concentration as predictors of DAM. Neither of these variables can be argued to be entirely unrelated to the pressure of acidification for reasons explained below, but both are considered relatively stable, in comparison with more direct acidity indicators such as $\mathrm{H}^{+}$and $\mathrm{Al}^{3+}$ concentrations.

Calcium is a simple measure of the buffering capacity of a site and tends to be relatively stable, in comparison with changes in acid anions, during the process of acidification and recovery. Similarly, TOC concentration is primarily an intrinsic feature of the site that is controlled by catchment characteristics (see, for example Monteith et al., 2015). TOC concentrations have approximately doubled at most UWMN sites over the first 2 decades of monitoring, a feature that is thought to be directly linked to reductions in acid deposition (Monteith et al., 2014). Nevertheless, mean TOC concentrations over the 20 years clearly discriminate, for example, between high altitude sites dominated by organo-mineral soils (circa 1-4 $\mathrm{mg} \mathrm{L}^{-1}$ ) and lower altitude sites draining peatlands (circa 8-15 $\mathrm{mg} \mathrm{L}^{-1}$ ). In oligotrophic waters TOC primarily reflects the concentration of humic acids, which represents both a direct source of weak acidity and also a buffer against the toxic effects of dissolved aluminium (Al) at low pH (Gensemer and Playle, 1999). Consequently it is included as a potential predictor of "expected" values for DAM. 
A series of regression models were developed with $\mathrm{Ca}^{2+}$ (alone) and with both $\mathrm{Ca}^{2+}$ and TOC to predict reference DAM scores. The minimum adequate model was one that included terms for both $\mathrm{Ca}^{2+}$ and TOC. Quadratic and interaction terms were also tested and were not significant ( $p>0.01$ ). The final model is given in Equation 3 has an adjusted r-squared value of 0.54 .

Expected DAM $=-5.53+33.2 \log _{10}\left(\mathrm{Ca}^{2+}\right)-1.91 \mathrm{TOC}$

Equation 3
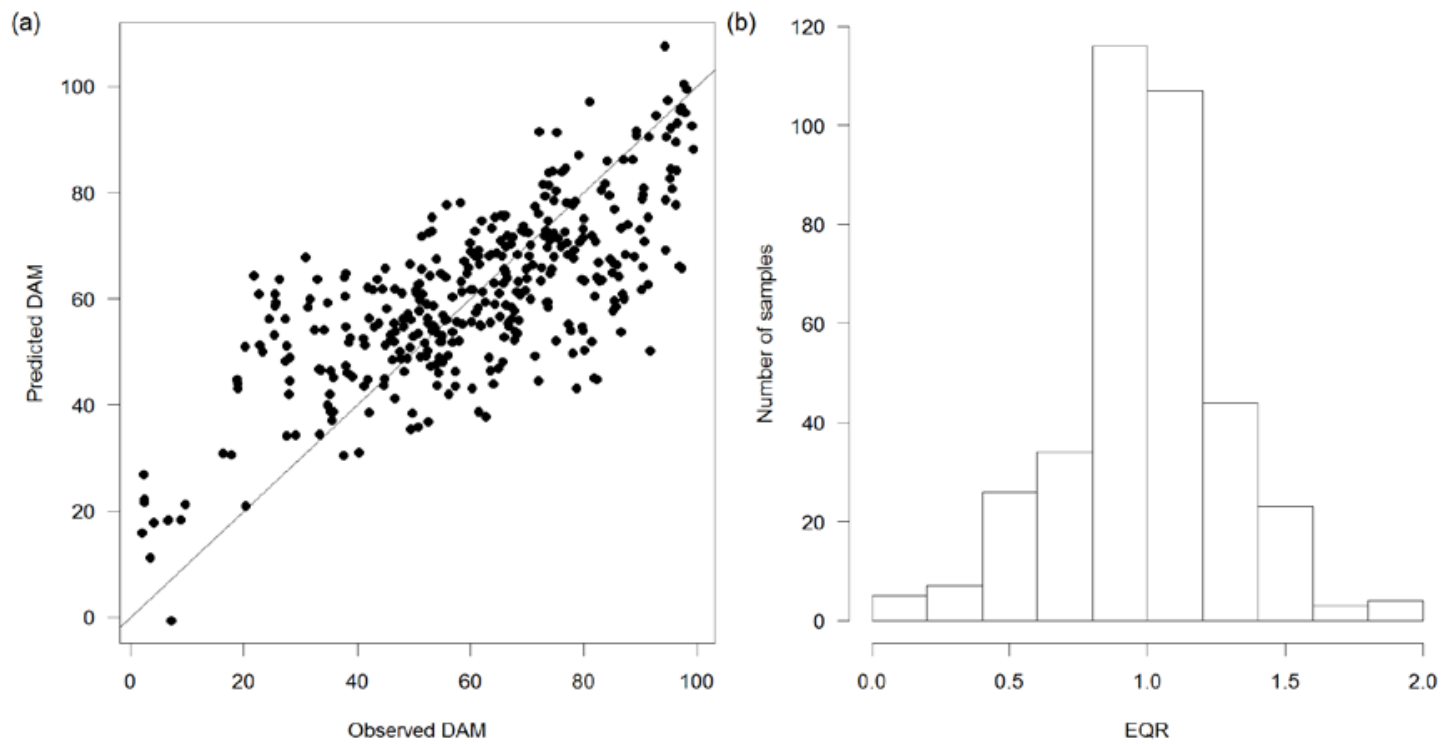

Figure 2. Relationship between observed and predicted Diatom Acidification Metric (DAM) (a), and distribution of EQRs (b), both for samples in the reference dataset.

Figure 2a shows the relationship between observed and predicted DAM for the reference samples. There is a slight tendency to under-estimate DAM at high values and overestimate at low. EQRs were then calculated using the relationship EQR $=\mathrm{O} / \mathrm{E}$, where $\mathrm{O}$ is the observed and $\mathrm{E}$ is the expected values, predicted using the regression model defined above.

Figure $2 \mathrm{~b}$ shows the distribution of EQRs in the reference dataset. The majority fall between 0.8 and 1.2 but there are a few reference samples with EQR less than 0.2, suggesting that the reference dataset contains a number of samples from impacted sites. A cautionary approach was therefore adopted in setting the High-Good (HG) boundary and the $25^{\text {th }}$ percentile of the reference EQRs was used to allow for the fact that some samples may actually not be from sites at reference condition. EQRs greater than 1.0 were set to 1.0 in subsequent calculations.

In order to define the good/moderate status class boundary we used the predicted regression model defined above to calculate the "expected" DAM values for reference sites sharing similar $\mathrm{Ca}^{2+}$ and TOC concentrations, and, thus, and EQRs for the full dataset (that is, both reference and non-reference samples). When EQR is high, samples are dominated by acid sensitive taxa (defined as groups 1-2) whilst as EQR declined (representing an increase in acidification pressure) so the proportion of acid-tolerant taxa increased. 


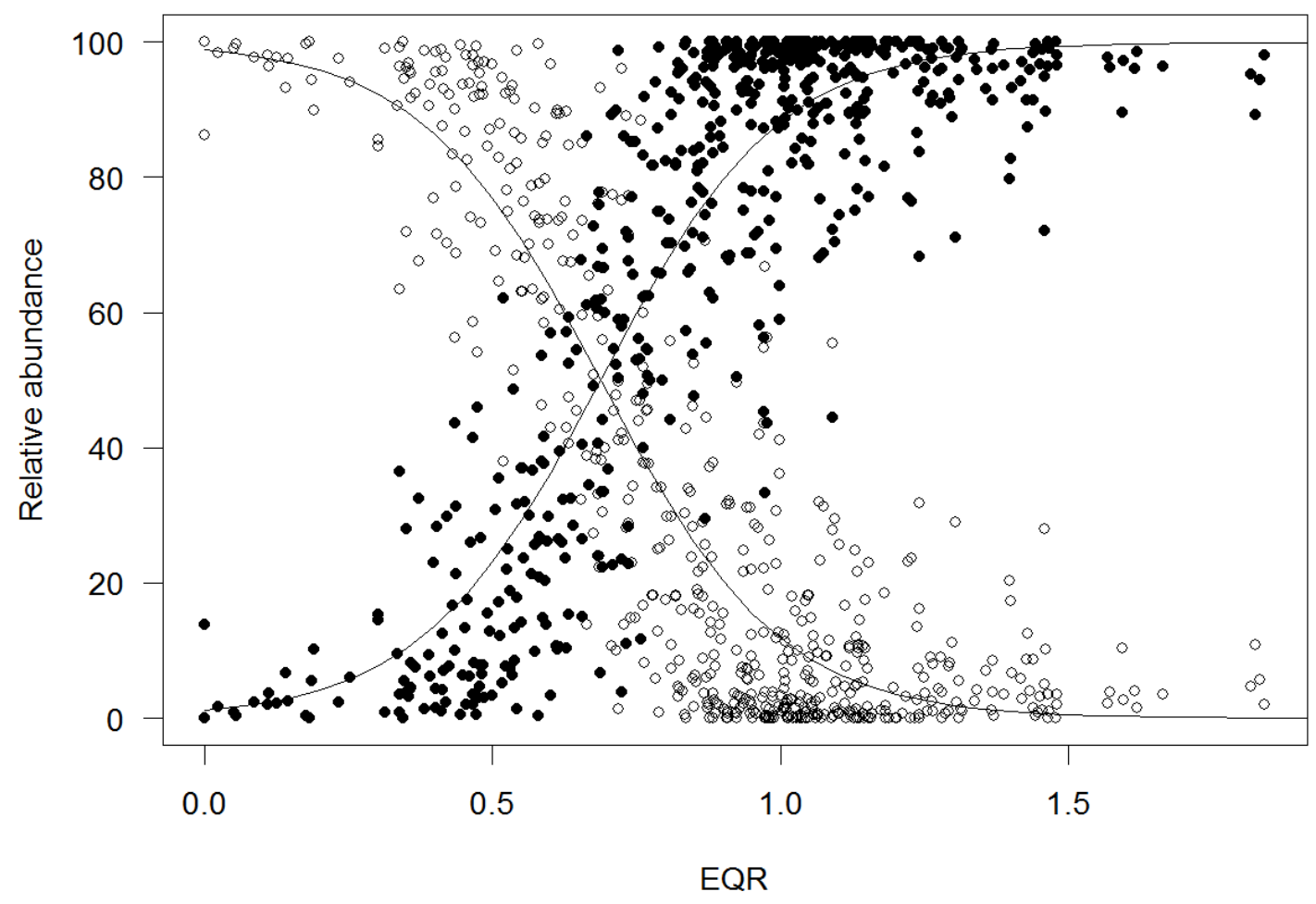

Figure 3. Relationship between the relative abundance of acid sensitive (open) and tolerant (filled) taxon groups and EQR. Lines show fitted logistic regression models used to identify the cross-over point.

The point at which the "sensitive" taxa cross the "tolerant" taxa (the "crossover") represents the point at which assemblages typical of reference conditions become subordinate to assemblages indicative of acidification and this was chosen as a suitable location for the good/moderate boundary (Figure 3). The moderate/poor and poor/bad status class boundaries are set at equal points below the good/moderate boundary. The resulting class boundaries are listed in Table 2 .

Table 2. Status class boundaries for use with the DAM tool

\begin{tabular}{lcccc}
\hline $\begin{array}{l}\text { Explanatory } \\
\text { Variables }\end{array}$ & H/G & G/M & $\mathbf{M} / \mathbf{P}$ & $\mathbf{P} / \mathbf{B}$ \\
\hline EQR & 0.81 & 0.65 & 0.44 & 0.22 \\
\hline
\end{tabular}

\subsection{Validation of the DAM tool}

A validation exercise using a test dataset of samples from the UKUWMN was carried out. This dataset contains annual epilithic diatom samples from 11 stream sites beginning in 1988, and spanning a range of sites from sensitive unimpacted streams in NW Scotland to chronically acidified sites in Southern England. Full associated chemical and other biological data were also available and the sites have been the subject of several detailed investigation into their chemical and biological status and trajectories (Battarbee et al., 2014a). Three years of data from 1990-1992, the most acidic phase for the UWMN and prior to the onset of later significant chemical recovery, were selected 
for use. Table 3 lists the DAM-derived quality classes alongside a qualitative summary of acidification status derived from long-term chemical and biological monitoring and quantitative summaries of the distributions of $\mathrm{pH}$, labile aluminium and ANC for the validation period.

\section{Insert Table 3 here.}

The diatom assessment agreed well with status derived from long-term chemical and biological monitoring. In particular the tool discriminates between high, moderate and poor sites indicated by no, episodic or chronic negative ANC values (and corresponding low to high labile aluminium concentrations) respectively, but fails to identify mildly acidified sites subject to acid episodes at high flow. This is likely to be because of the time of sampling: the validation diatom samples were collected over summer, often during predominantly low flow conditions when sites are buffered by input of cations from baseflow. This sampling period misses episodic winter / early spring / late autumn low-pH and low alkalinity high flow events. This effect is particularly apparent in samples from the River Etherow where two samples capture higher $\mathrm{pH}$ conditions characterised by A. minutissimum assemblages and only one sample, collected in 1991 and characterised by the acid tolerant taxon Eunotia exigua, reflects the chronically acidified nature of this site.

\section{Discussion}

The importance of $\mathrm{pH}$ in controlling the distribution and abundance of diatoms in freshwater systems has long been recognised (e.g. Hustedt, 1937-39). The strength of this relationship has been exploited in palaeolimnology where it has been quantified in transfer functions (e.g. Birks et al., 1990) and used to reconstruct, or hindcast, past changes in lake-water $\mathrm{pH}$ from sub-fossil diatom assemblages preserved in lake sediments (Battarbee et al., 2010a). Similar strong relationships between diatom assemblage composition and mean $\mathrm{pH}$ have also been observed in flowing waters (e.g. Andrén and Jarlman, 2008; Stevenson et al., 2010).

Although the ordination and variance partitioning demonstrated that $\mathrm{pH}$ explained a relatively small fraction of the total variation in the diatom data (4.1\%) such low values are typical for large, species rich datasets with many zeros in the data matrix (ter Braak, 1986). The $\mathrm{pH}$ axis is highly significant and demonstrates that $\mathrm{pH}$ is a primary factor controlling assemblage composition in the dataset presented here. The correlations between the new Diatom Acidification Metric (DAM) and measured mean stream-water $\mathrm{pH}$ are high with values of $\mathrm{r}=0.81$ and $\mathrm{r}=0.77$ for the full and reference datasets, respectively, and demonstrate that the relationship between diatom distribution and $\mathrm{pH}$ has been effectively encapsulated in the new metric. These results, and those from other studies, indicate that diatoms provide a powerful tool for the assessment of stream-water acidity. However, the main challenge in developing a metric for assessing ecological status in soft waters is to differentiate between those water bodies which are naturally acid and those which have been acidified due to human impact. Palaeolimnology has played an important role in establishing pre-impact conditions in lakes (Battarbee et al., 2010a) but equivalent methods are not available for running waters. The alternative is to infer the reference state for any site by a space-for-time substitution, using a dataset of sites presumed to be free from significant acidification. 
Variables used to predict "expected" values of metrics need to be independent of the pressure under consideration, ruling out the use of alkalinity, as used for evaluations of nutrient impacts (Kelly et al., 2008). Calcium, derived largely from catchment geology, is also a reliable predictor of the expected flora; however it, too, is not wholly immune from the pressure. Keller (2009) presents data showing a decline in calcium concentration in Clearwater Lake, near Sudbury, Ontario, as $\mathrm{pH}$ increased during recovery from acidification. This reflects both reduced chemical weathering and increased availability of cation binding sites as $\mathrm{H}^{+}$concentrations decline. The relationship between current and pre-industrial base cations has been modelled in the Steady State Water Chemistry Model (SSWC: Henriksen et al., 1992 ). Unfortunately the majority of sites in our database lack the sulphate and nitrate data necessary for detailed modelling but studies elsewhere suggest that the increase in base cations as a result of acidification is less than $20 \%$ for the majority of sites, and less than $15 \%$ for sites with $\mathrm{Ca}^{2+}<50 \mu \mathrm{eq} \mathrm{L}^{-1}$.

Problems will also arise if the present system is used to evaluate changes when liming is used as a remediation technique. This work has shown evidence of natural changes along a $\mathrm{Ca}^{2+}$ gradient, even in the absence of acidification, and liming will, itself, have ancillary effects that may influence the diatom assemblage (e.g. P sequestration: Anderson et al., 1997). Adding lime will, by raising the $\mathrm{Ca}^{2+}$ concentration, alter the "expected" value. However, the gradual removal of the lime from the catchment may lead to a fall in $\mathrm{Ca}^{2+}$ and re-establishment of an acid flora (e.g. Bellemakers \& van Dam, 1992). Monitoring would consequently take place against a fluctuating baseline whilst the remediation itself may mean that the true "expected" flora will never be regained.

The bicarbonate system is the predominant buffer for most non-acid UK waters although TOC, representing the input of weak organic acids, becomes important at low $\mathrm{Ca}^{2+}$ (Schneider, 2011). The importance of TOC in influencing the distribution of diatoms in our dataset is demonstrated by the ordination and variance partitioning reported in Section 3.1, where the spread of taxa along the TOC gradient is particularly pronounced at low $\mathrm{pH}$. Similarly, there is evidence for the importance of TOC as a source of weak organic acids in the regression model for the "expected" DAM, where TOC has a negative coefficient (Equation 3). Calcium and TOC, as predictors of the expected flora under reference (pre-industrial) conditions, explain approximately half the variation in DAM. This is a reasonable proportion given the uncertainties in both the diatom and hydrochemistry data and the relative simplicity of the predictive model. A similar model developed for assessing nutrient impacts explained only 33\% of the expected index (Kelly et al., 2008). The model for "expected" values of DAM was generated from a relatively large dataset of reference samples, although most of these samples fell in the range $\mathrm{pH} 6.5-7.0$. The reference dataset contained few sites with $\mathrm{pH}<6$, which accounts for some of the bias in the regression model (Figure 2), and the over prediction of DAM in more acid waters. Future work should prioritise samples from low $\mathrm{pH}$ reference systems.

The model was validated using time-series data from a series of well-studied catchments. In most cases the predicted status class agreed well with the status derived from chemical and invertebrate analyses. Where there was disagreement this could be attributed to the episodic acidic nature of the sites. Diatoms can respond to changes in water chemistry in a matter of days (e.g. Hirst et al., 2004) and recent work has shown that diatoms exhibit different responses to chronic and episodic acidification (e.g. Passy, 2006). 
Unfortunately detailed time-series chemistry is not available for the calibration samples, so it was not possible to explore the response of diatom assemblage structure to episodic versus mean chemistry in this study. However, given the rapid temporal response of diatoms to changes in chemistry it is clearly important to sample at the appropriate time of year to encompass any episodes of low $\mathrm{pH}$ and ANC during periods of high flow. If appropriate sampling can be achieved then the new DAM provides a relatively simple but effective way of assessing the ecological status of UK and Irish softwaters.

\section{Conclusions}

A new diatom-based method for quantifying the magnitude of impact of rivers affected by acidification is described. The approach uses $\mathrm{Ca}^{2+}$ and TOC, two variables that are easily and routinely measured, to calculate a Diatom Acidification Metric (DAM) score expected for a comparable site at reference conditions and compares this to the observed score inferred from the sampled diatom assemble. The resulting Ecological Quality Ratio (EQR) provides a measure to classify the water body in terms of acidification status that is compliant with the EU Water Framework Directive. Validation using long-term monitoring data indicated that in most cases the predicted status class agreed well with the status derived from chemical and invertebrate analyses, although the episodic nature of some sites, and the rapid response of diatoms to changes in water chemistry means that care is needed to schedule sample collection in order to capture any potential acid episodes.

\section{Acknowledgements}

This work was funded by the UK Environment Agency and Scottish Environment Protection Agency. Early years data from the UKUWMN analysed in this study was funded by Defra and the FORWATER data were collected as part of a project funded by Galway County Council, Western River Basin District Project. We are grateful to Rachel Benstead, Robin Guthrie and two anonymous reviewers for comments on an earlier draft and to Ewan Shilland for providing access to the UKUWMN dataset.

\section{References}

Allott TEH, Harriman R, Battarbee RW. Reversibility of lake acidification at the Round Loch of Glenhead, Galloway, Scotland. Environmental Pollution 1992; 77: 219225.

Anderson NJ, Blomqvist P, renberg I. An experimental and palaeoecological study of algal responses to lake acidification and liming in three central Swedish lakes. European Journal of Phycology 1997; 32: 35-48.

Andrén C, Jarlman A. Benthic diatoms as indicators of acidity in streams. Fundamental and Applied Limnology / Archiv für Hydrobiologie 2008; 173: 237-253.

Battarbee R, Charles D, Bigler C, Cumming B, Renberg I. Diatoms as indicators of surface-water acidity. In: Smol JP, Stoermer EF, editors. The Diatoms: Applications for the Environmental and Earth Sciences. Cambridge University Press, Cambridge, 2010a, pp. 98-121.

Battarbee RW. Diatom analysis. In: Berglund BE, editor. Handbook of Holocene Palaeohydrology and Palaeoecology. John Wiley \& Sons, Chichester, 1986, pp. 527-570. 
Battarbee RW, Shilland EM, Kernan M, Monteith DT, Curtis CJ. Recovery of acidified surface waters from acidification in the United Kingdom after twenty years of chemical and biological monitoring (1988-2008). Ecological Indicators 2014a; 37: 267-273.

Battarbee RW, Simpson GL, Bennion H, Curtis C. A reference typology of low alkalinity lakes in the UK based on pre-acidification diatom assemblages from lake sediment cores. Journal of Paleolimnology 2010b; 45: 489-505.

Battarbee RW, Simpson GL, Shilland EM, Flower RJ, Kreiser A, Yang H, et al. Recovery of UK lakes from acidification: An assessment using combined palaeoecological and contemporary diatom assemblage data. Ecological Indicators 2014b; 37: 365-380.

Bennion H, Battarbee RW, Sayer CD, Simpson GL, Davidson TA. Defining reference conditions and restoration targets for lake ecosystems using palaeolimnology: a synthesis. Journal of Paleolimnology 2010; 45: 533-544.

Birks HJB, Line JM, Juggins S, Stevenson AC, ter Braak CJF. Diatoms and pH reconstruction. Philosophical Transactions of the Royal Society of London, B 1990; 327: 263-278.

Borcard D, Legendre P, Drapeau P. Partialling out the Spatial Component of Ecological Variation. Ecology 1992; 73: 1045-1055.

CEN. Water Quality - Guidance Standard for the Routine Sampling and Pretreatment of Benthic Diatoms from Rivers. EN 13946:2003, Geneva, 2003.

CEN. Water Quality - Guidance Standard for the Identification, Enumeration and Interpretation of Benthic Diatom Samples from Running Water. EN 14407:2004, Geneva, 2004.

Coring E. Use of diatoms for monitoring acidification in small mountain rivers in Germany with special emphasis on "diatom assemblage type analysis" (DATA). In: Whitton BA, Rott E, editors. Use of Algae for Monitoring Rivers II. Institut für Botanik, Universität Innsbruck, Innsbruck, 1996, pp. 7-16.

Curtis CJ, Battarbee RW, Monteith DT, Shilland EM. The future of upland water ecosystems of the UK in the 21st century: A synthesis. Ecological Indicators 2014; 37: 412-430.

Derwent RG, Wilson RB. Acidification Research: Evaluation and Policy Applications, A United Kingdom Policy Response. In: Schneider $\mathrm{T}$, editor. Studies in Environmental Science. Volume 50. Elsevier, 1992, pp. 253-256.

European Union. Directive 2000/60/EC of the European Parliament and of the Council of 23 October 20000 establishing a framework for Community action in the field of water policy. Official Journal of the European Communities 2000; L327: 173.

Feeley HB, Bruen M, Blacklocke S, Kelly-Quinn M. A regional examination of episodic acidification response to reduced acidic deposition and the influence of plantation forests in Irish headwater streams. Science of the Total Environment 2013; 443: 173-83.

Flower R, Battarbee R. Diatom evidence for recent acidification of two Scottish Lochs. Nature 1983; 305: 130-133.

Fourtanier E, Kociolek JP. Catalogue of the diatom genera. Diatom Research 1999; 14: 1-190.

Fourtanier E, Kociolek JP. Addendum to "Catalogue of the diatom genera". Diatom Research 2003; 18: 254-258. 
Gensemer RW, Playle RC. The Bioavailability and Toxicity of Aluminum in Aquatic Environments. Critical Reviews in Environmental Science and Technology 1999; 29: 315-450.

Guhrén M, Bigler C, Renberg I. Liming placed in a long-term perspective: a paleolimnological study of 12 lakes in the Swedish liming program. Journal of Paleolimnology 2006; 37: 247-258.

Hartley B, Barber H, Carter J. An Atlas of British Diatoms Bristol: Biopress, 1996.

Henriksen A, Kämäri J, Posch M, Wilander A. Critical loads of acidity: Nordic surface waters. Ambio 1992; 21: 356-363.

Hirst H, Chaud F, Delabie C, Juttner I, Ormerod SJ. Assessing the short-term response of stream diatoms to acidity using inter-basin transplantations and chemical diffusing substrates. Freshwater Biology 2004; 49: 1072-1088.

Hustedt F. Systematische und ökologische Untersuchungen über den Diatomeen-Flora von Java, Bali, Sumatra. Archiv für Hydrobiologie 1937-39; 15 \& 16.

Keller W. Limnology in northeastern Ontario: from acidification to multiple stressors. Canadian Journal of Fisheries and Aquatic Sciences 2009; 66: 1189-1198.

Kelly-Quinn M, Cruikshanks R, Johnson J, Matson R, Baars J-R, Bruen M. Forestry and Surface Water Acidification (FORWATER). University College Dublin, Dublin, 2008, pp. 81.

Kelly M, Juggins S, Guthrie R, Pritchard S, Jamieson J, Rippey B, et al. Assessment of ecological status in UK rivers using diatoms. Freshwater Biology 2008; 53: 403422.

Kernan M, Curtis C. Critical loads of acidity and metals: Interim Report to the Department of Environment, Transport and the Regions (Contract no. EPG/1/3/117). ECRC Research Reports. 64. ECRC, University College London London, 2000, pp. 63.

Kowalik RA, Cooper DM, Evans CD, Ormerod SJ. Acidic episodes retard the biological recovery of upland British streams from chronic acidification. Global Change Biology 2007; 13: 2439-2452.

Krammer K, Lange-Bertalot H. Bacillariophyceae 1, Naviculaceae. Stuttgart: Gustav Fischer-Verlag, 1986.

Krammer K, Lange-Bertalot H. Bacillariophyceae 2, Bacillariaceae, Epithemiaceae, Surirellaceae. Stuttgart: Gustav Fischer-Verlag, 1988.

Krammer K, Lange-Bertalot H. Bacillariophyceae 3, Centrales, Fragilariaceae, Eunotiaceae. Stuttgart: Gustav Fischer-Verlag, 1991.

Kwandrans J. Diversity and ecology of benthic diatom communities in relation to acidity, acidification and recovery of lakes and rivers. Diatom Monographs 2007; 9: 169pp.

Lien L, Raddum GD, Fjellheim A, Henriksen A. A critical limit for acid neutralizing capacity in Norwegian surface waters, based on new analyses of fish and invertebrate responses. Science of the Total Environment 1996; 177: 173-193.

Malcolm IA, Gibbins CN, Fryer RJ, Keay J, Tetzlaff D, Soulsby C. The influence of forestry on acidification and recovery: Insights from long-term hydrochemical and invertebrate data. Ecological Indicators 2014; 37: 317-329.

McCartney AG, Harriman R, Watt AW, Moore DW, Taylor EM, Collen P, et al. Longterm trends in $\mathrm{pH}$, aluminium and dissolved organic carbon in Scottish fresh waters; implications for brown trout (Salmo trutta) survival. Science of The Total Environment 2003; 310: 133-141.

Monteith D, Simpson G. Macroinvertebrate classification diagnostic tool development. Final Report. Project WDF60, Edinburgh, 2007. 
Monteith DT, Evans CD, Henrys PA, Simpson GL, Malcolm IA. Trends in the hydrochemistry of acid-sensitive surface waters in the UK 1988-2008. Ecological Indicators 2014; 37: 287-303.

Monteith DT, Henrys PA, Evans CD, Malcolm I, Shilland EM, Pereira MG. Spatial controls on dissolved organic carbon in upland waters inferred from a simple statistical model. Biogeochemistry 2015; 123: 363-377.

Oksanen J, Blanchet F, Kindt R, Legendre P, Minchin P, O'Hara R, et al. vegan: Community Ecology Package, $\mathrm{R}$ package version 2.4-0. http://CRAN.Rproject.org/package=vegan, 2015.

Ormerod SJ, Durance I. Restoration and recovery from acidification in upland Welsh streams over 25 years. Journal of Applied Ecology 2009; 46: 164-174.

Pardo I, Gómez-Rodríguez C, Wasson J-G, Owen R, van de Bund W, Kelly M, et al. The European reference condition concept: A scientific and technical approach to identify minimally-impacted river ecosystems. Science of The Total Environment 2012; 420: 33-42.

Passy SI. Diatom community dynamics in streams of chronic and episodic acidification: The roles of environment and time. Journal of Phycology 2006; 42: 312-323.

Patrick S, Battarbee R, Jenkins A. Monitoring acid waters in the U.K.: An overview of the UK Acid Waters Monitoring Network and summary of the first interpretative exercise. Freshwater Biology 1996; 36.

R Core Team. R: A language and environment for statistical computing. R Foundation for Statistical Computing, Vienna, Austria. Version 3.2.2. http://www.Rproject.org/. 2015.

Renberg I, Hellberg T. The pH history of lakes in Southwestern Sweden, as calculated from the subfossil flora of the sediments. Ambio 1982; 11: 30-33.

Reynolds B, Lowe JAH, Smith RI, Norris DA, Fowler D, Bell SA, et al. Acid deposition in Wales: the results of the 1995 Welsh Acid Waters Survey. Environmental Pollution 1999; 105: 251-266.

Round F, Crawford R, MAnn D. The Diatoms: Biology and Morphology of the Genera: Cambridge University Press, 1990.

Schneider SC. Impact of calcium and TOC on biological acidification assessment in Norwegian rivers. Sci Total Environ 2011; 409: 1164-71.

Stevenson J, Pan Y, van Dam H. Assessing environmental conditions in rivers and streams with diatoms. In: Stoermer EF, Smol JP, editors. The Diatoms: Applications for the Environmental and Earth Sciences. Cambridge University Press, Cambridge, 2010, pp. 57-85.

Stoddard JL, Jeffries DS, Lukewille A, Clair TA, Dillon PJ, Driscoll CT, et al. Regional trends in aquatic recovery from acidification in North America and Europe. Nature 1999; 401: 575-578.

Stoddard JL, Larsen DP, Hawkins CP, Johnson RK, Norris RH. Setting expectations for the ecological conditions of streams: The concept of reference condition. Ecological Applications 2006; 16: 1267-1276.

ter Braak CJF. Canonical correspondence analysis: a new eigenvector technique for multivariate direct gradient analysis. Ecology 1986; 67: 1167-1179.

ter Braak CJF, Barendregt LG. Weighted averaging of species indicator values: Its efficiency in environmental calibration. Mathematical Biosciences 1986; 78: 5772.

ter Braak CJF, Looman CWN. Weighted averaging, logistic regression and the Gaussian response model. Vegetatio 1986; 65: 3-11. 
Van Dam H, Mertens A. Long-term changes of diatoms and chemistry in headwater streams polluted by atmospheric deposition of sulphur and nitrogen compounds. Freshwater Biology 1995; 34: 579-600.

van Dam H, Mertens A, Sinkeldam J. A coded checklist and ecological indicator values of freshwater diatoms from the Netherlands. Netherlands Journal of Aquatic Ecology 1994; 28: 117-133.

Wallin M, Wiederholm T, Johnson R. Guidance on Establishing Reference Conditions and Ecological Status Class Boundaries for Inland Surface Waters. CIS Working Group 2.3 - REFCOND. 7th Version., 2003, pp. 93.

Whitton B, John D, Johnson L, Boulton P, Kelly M, Haworth E. Perspective on the 'coded list of the freshwater algae of the British Isles'. Science of The Total Environment 1998; 210-211: 283-288. 


\section{Appendix 1}

List of codes and names shown in Figures for all taxa with at least $10 \%$ relative abundance in at least one sample.

\begin{tabular}{|c|c|c|}
\hline Code & Name & DAM Score \\
\hline AC083A & Achnanthes laevis & 2 \\
\hline AC143A & Achnanthes oblongella & 3 \\
\hline AC182A & Achnanthes rosenstockii & 3 \\
\hline AM012A & Amphora pediculus & 5 \\
\hline BR001A & Brachysira vitrea & 3 \\
\hline BR006A & Brachysira brebissonii fo. brebissonii & 2 \\
\hline CM004A & Cymbella microcephala fo. microcephala & 3 \\
\hline CM022A & Cymbella affinis & 5 \\
\hline CO001A & Cocconeis placentula & 5 \\
\hline DE001A & Denticula tenuis & 4 \\
\hline DT002A & Diatoma hyemale var. hyemale & 3 \\
\hline DT021A & Diatoma mesodon & 4 \\
\hline EU002A & Eunotia pectinalis & 2 \\
\hline EU003A & Eunotia praerupta & 1 \\
\hline EU004A & Eunotia tenella & 1 \\
\hline EU009A & Eunotia exigua & 2 \\
\hline EU011A & Eunotia rhomboidea & 1 \\
\hline EU013A & Eunotia arcus & 1 \\
\hline EU015A & Eunotia denticulata var. denticulata & 2 \\
\hline EU020A & Eunotia meisteri & 1 \\
\hline EU026A & Eunotia praerupta-nana & 3 \\
\hline EU040A & Eunotia paludosa & 1 \\
\hline EU040B & Eunotia paludosa var. trinacria & 1 \\
\hline EU047A & Eunotia incisa & 1 \\
\hline EU048A & Eunotia naegelii & 2 \\
\hline EU049D & Eunotia curvata var. attenuata & 3 \\
\hline EU053A & Eunotia tridentula & 3 \\
\hline EU070A & Eunotia bilunaris & 1 \\
\hline EU105A & Eunotia subarcuatoides & 2 \\
\hline EU107A & Eunotia implicata & 3 \\
\hline EU108A & Eunotia intermedia & 3 \\
\hline EU110A & Eunotia minor & 3 \\
\hline EU114A & Eunotia muscicola & 3 \\
\hline EU9999 & Eunotia sp. & 2 \\
\hline EY011A & Encyonema minutum & 4 \\
\hline EY016A & Encyonema silesiacum & 4 \\
\hline EY017A & Encyonema gracile & 3 \\
\hline FF001A & Fragilariforma virescens & 1 \\
\hline FR007A & Fragilaria vaucheriae & 3 \\
\hline FR009A & Fragilaria capucina & 3 \\
\hline FR026A & Fragilaria bidens & 4 \\
\hline
\end{tabular}


FU002A Frustulia rhomboides $\quad 1$

FU027A Frustulia saxonica 1

GO001A Gomphonema olivaceum 4

GO003A Gomphonema angustatum 3

GO004A Gomphonema gracile 3

GO013A Gomphonema parvulum 4

GO029A Gomphonema clavatum 4

GO052A Gomphonema olivaceoides 4

HN001A Hannaea arcus 4

MR001A Meridion circulare 4

NA009A Navicula lanceolata 4

NA023A Navicula gregaria 4

NA042A Navicula minima 4

NA138A Navicula pelliculosa 4

NA352A Navicula evanida 4

NA415A Navicula harderi 3

NA669A Navicula suchlandtii 4

NA751A Navicula cryptotenella 3

NI002A Nitzschia fonticola 5

NI009A Nitzschia palea 4

NI015A Nitzschia dissipata 4

NI025A Nitzschia recta 3

NI033A Nitzschia paleacea 4

PE002A Peronia fibula 2

PI014A Pinnularia appendiculata 1

PI022A Pinnularia subcapitata 1

RE001A Reimeria sinuata 4

SA012A Stauroneis kriegeri 3

SS002A Staurosirella pinnata 5

SU004A Surirella biseriata var. biseriata 3

SY001A Synedra ulna 4

TA001A Tabellaria flocculosa 3

TA004A Tabellaria quadriseptata 1

TA006A Tabellaria ventricosa 2

ZZZ834 Gomphonema angustum/pumilum type 5

ZZZ835 Achnanthidium minutissimum type 5

ZZZ841 Fragilariforma exigua 2

ZZZ852 Psammothidium helveticum 3

ZZZ854 Psammothidium marginulatum 3

ZZZ896 Planothidium frequentissimum 4

ZZZ897 Planothidium lanceolatum 5

ZZZ911 Achnanthidium subatomus 5

ZZZ922 Planothidium sp. 3

ZZZ949 Psammothidium subatomoides 3 
Table 3. DAM derived quality status classes for the UKUWMN validation sites and summary of status based on long-term chemical and biological monitoring.

\begin{tabular}{|c|c|c|c|c|c|c|c|c|c|c|c|c|c|}
\hline \multirow{3}{*}{$\begin{array}{l}\text { Site } \\
\begin{array}{l}\text { Allt a’Mharcaidh } \\
\text { (Cairngorms) }\end{array}\end{array}$} & \multicolumn{3}{|c|}{ DAM Status } & \multirow{3}{*}{$\begin{array}{l}\text { Status derived from chemical and other } \\
\text { biology }\end{array}$} & \multicolumn{9}{|c|}{ Chemical ranges $\left(10^{\text {th }}, 50^{\text {th }}, 90^{\text {th }}\right.$ percentiles $)$} \\
\hline & \multirow{2}{*}{1990} & \multirow{2}{*}{$\begin{array}{l}1991 \\
\text { High }\end{array}$} & 1992 & & \multicolumn{3}{|c|}{ pH range } & \multicolumn{3}{|c|}{ Labile Al $\left(\mu g L^{-1}\right)$} & \multicolumn{3}{|c|}{ ANC $\left(\mu \mathrm{eq} \mathbf{L}^{-1}\right)$} \\
\hline & & & High & & 5.9 & 6.5 & 6.8 & 2 & 5 & 15 & 31 & 51 & 80 \\
\hline $\begin{array}{l}\text { Allt na Coire nan } \\
\text { Con (NW Scotland) }\end{array}$ & High & High & High & $\begin{array}{l}\text { Mildly acidic, with occasional acid } \\
\text { episodes. Strong seasonality in chemistry. }\end{array}$ & 5.2 & 5.7 & 6.4 & 2 & 15 & 39 & 2 & 30 & 70 \\
\hline $\begin{array}{l}\text { Dargall Lane } \\
\text { (Galloway) }\end{array}$ & Moderate & Poor & Moderate & $\begin{array}{l}\text { Mildly acidic suffering frequent acid } \\
\text { episodes that reduce } \mathrm{pH} \text { to }<5 \text { and } \\
\text { alkalinity to }<0 \text {. }\end{array}$ & 5.0 & 5.3 & 6.0 & 7 & 37 & 91 & -12 & 2 & 26 \\
\hline $\begin{array}{l}\text { River Etherow } \\
\text { (Pennines) }\end{array}$ & High & Poor & High & $\begin{array}{l}\text { Impacted site with high } \mathrm{SO}_{4} \text { and } \mathrm{NO}_{x} \text {; well } \\
\text { buffered by catchment cations at low flow } \\
\text { but subject to occasional extreme acid } \\
\text { episodes. }\end{array}$ & 4.1 & 5.0 & 6.7 & 2 & 57 & 240 & -99 & -1 & 104 \\
\hline $\begin{array}{l}\text { Old Lodge } \\
\text { (SE England) }\end{array}$ & Poor & Poor & Poor & $\begin{array}{l}\text { Severely acidified with mean } \mathrm{pH}<5 \text { and } \\
\text { almost continuous negative alkalinity. }\end{array}$ & 4.4 & 4.6 & 4.6 & 111 & 265 & 320 & -55 & -46 & -20 \\
\hline $\begin{array}{l}\text { Narrator Brook } \\
\text { (Dartmoor) }\end{array}$ & High & High & High & $\begin{array}{l}\text { Mildly acidic with occasional acid } \\
\text { episodes that cause alkalinity to fall below } \\
\text { zero. }\end{array}$ & 5.5 & 5.8 & 6.1 & 4 & 15 & 48 & 9 & 19 & 45 \\
\hline $\begin{array}{l}\text { Afon Hafren } \\
\text { (Plynlimon) }\end{array}$ & Moderate & Moderate & Moderate & $\begin{array}{l}\text { Moderately acidic site with frequent acid } \\
\text { episodes and occasional negative } \\
\text { alkalinity. }\end{array}$ & 4.5 & 5.1 & 5.9 & 19 & 108 & 242 & -42 & -9 & 18 \\
\hline
\end{tabular}




\begin{tabular}{|c|c|c|c|c|c|c|c|c|c|c|c|c|c|}
\hline $\begin{array}{l}\text { Afon Gwy } \\
\text { (Plynlimon) }\end{array}$ & No data & Moderate & Moderate & $\begin{array}{l}\text { Moderately acidic site with frequent acid } \\
\text { episodes and occasional negative } \\
\text { alkalinity. }\end{array}$ & 4.7 & 5.4 & 5.9 & 3 & 46 & 112 & -16 & 11 & 35 \\
\hline $\begin{array}{l}\text { Beagh’s Burn } \\
\text { (C. Antrim) }\end{array}$ & Moderate & High & High & $\begin{array}{l}\text { Mildly acidic, relatively unimpacted site } \\
\text { with occasional acid episodes. }\end{array}$ & 4.7 & 5.7 & 6.6 & 2 & 7 & 42 & 9 & 71 & 179 \\
\hline $\begin{array}{l}\text { Bencrom River } \\
\text { (Mourne Mtns) }\end{array}$ & Moderate & Poor & Poor & $\begin{array}{l}\text { Severely acidified site with frequent low } \\
\mathrm{pH}(<5) \text { and long periods of negative } \\
\text { alkalinity. }\end{array}$ & 4.6 & 5.1 & 5.6 & 51 & 126 & 220 & -33 & -1 & 17 \\
\hline $\begin{array}{l}\text { Coneyglen Burn } \\
\text { (Sperrin Hills) }\end{array}$ & High & High & Good & $\begin{array}{l}\text { Relatively unimpacted but subject to } \\
\text { occasional mild acid episodes. }\end{array}$ & 5.6 & 6.7 & 7.3 & 2 & 2 & 15 & 50 & 156 & 384 \\
\hline
\end{tabular}

